\title{
Managers View on Impact of Covid-19 Pandemic: Evidence from Hotel Industry in Malaysia
}

\author{
Hazrina Ghazali (Corresponding author) \\ Department of Food Service and Management \\ Faculty of Food Science and Technology \\ University Putra Malaysia \\ 43400 Serdang, Selangor, Malaysia
}

Maisarah Ishak

Faculty of Business Management,

Universiti Teknologi MARA Cawangan Pahang, Malaysia

Received: Nov. 8, 2020 Accepted: Dec. 14, 2020 Online published: Jan. 15, 2021

doi:10.5296/ijhrs.v11i1.17927ＵRL: https://doi.org/10.5296/ijhrs.v11i1.17927

\begin{abstract}
2020 is an important year which had been waiting for by the hotel industry in Malaysia. With the exciting slogan "Visit Truly Asia Malaysia," Malaysia was aimed by many to be one of the most chosen countries to be visited. This simultaneously gives a high hope to the hotel industry to generate more revenues. However, the COVID-19 pandemic has changed the hotel industry landscape tremendously. Therefore, the purpose of this research is to explore the impact of COVID-19 on the hotel industry in Malaysia. This study employed qualitative method and six hotel representatives were participated in this study. The interview data revealed experiences, voices, and opinions of the hotel informants on the impact of COVID-19. The informants also shared their immediate strategies and long-term plans in coping with the pandemic. In addition, the informants also shared information on the Tourism Stimulus Package offered by the Government that they have received.
\end{abstract}

Keywords: impact of COVID-19, hotel industry, interviews, Malaysia

\section{Introduction}

The 2019 Coronavirus Disease (COVID-19) originated first in December 2019 in Wuhan, the capital city of Hubei Province in the People's Republic of China. The World Health 


\section{Mll Macrothink}

International Journal of Human Resource Studies ISSN 2162-3058 2021, Vol. 11, No. 1

Organization (WHO) declared it a pandemic on 11th March 2020. To date, it has spread to 218 countries and 2 international conveyances as of 11 December 2020 with more than 70 million people infected and reached 1,591,263 deaths reported worldwide (Worldometers, 2020). In the six months since the outbreak of the COVID-19 pandemic the world has dramatically changed. In the present global situation the spread of this pandemic has influenced people in all respects. Malaysia, likewise, is no exception to this. The Government of Malaysia has taken drastic measures to overcome the spread of the pandemic while at the same time executing plans to reduce the economic impact of the pandemic. Currently, the number of COVID-19 cases in Malaysia has reached 80,309 with 405 total death cases (Ministry of Health, 2020). Malaysia is among the countries that have taken prevention early by imposing movement control to prevent massive loss of life. In an attempt to curb the spread of the virus, a partial lockdown called the Movement Control Order (MCO) was called on March 18, 2020, which was a first in the country's history. All economic activities were ordered to shut down except the essential industries, with international frontiers also being closed to foreigners. The MCO was put into service in four phases and lasted 47 days. This was followed by the Conditional Movement Control Order (CMCO) which was end on 9 June 2020.

Subsequently, the Prime Minister of Malaysia announced that the CMCO ended and replaced with the Recovery Movement Control Order (RMCO) which took effect from June 10, 2020 until August 31, 2020 with more lenient restrictions. Under this new phase, interstate travel permitted, except for areas placed under Enhanced MCO (EMCO). However, International travel is still not permitted as the country's borders remain shut during the new RMCO. Currently, most companies allow to resume operations but must adhered the guidelines and standard operating procedures introduced by the Malaysian Government. During the period of RMCO, further regulations should be simplified to allow the public to perform their everyday operations in compliance with standard operating procedures. On the other perspective, the impact of COVID-19 has been devastating to Malaysia's economy. Many companies in many industries across the country have been suffering due to the COVID-19 pandemic and sitting at the top of the list are the hotel industry. Other than loss hundreds of lives, this pandemic also cause paralyzed in an economic activity, which subsequently led to the unemployment. On top of that, close borders action taken by the Government has been a great blow to Malaysia's hotel industry. A total of 170,085 hotel room bookings during the period of 11 January 2020 until 16 March 2020 had been cancelled which caused a loss of revenue amounting to RM68,190,364 (Ying, 2020). Table 1 shows the details on severity of hotel room cancellation.

Table 1 . Severity of hotel cancellations

\begin{tabular}{llcc}
\hline Ranking & State & Room cancellations & $\begin{array}{c}\text { Losses due to room } \\
\text { cancellations RM }\end{array}$ \\
\hline 1 & Kuala Lumpur & 55,050 & $23,021,301$ \\
2 & Sabah & 32,392 & $11,550,605$ \\
3 & Pulau Pinang & 17,753 & $8,908,000$ \\
4 & Selangor & 22,929 & $7,212,048$
\end{tabular}


5

6

7

8

9

10

11

Total
Negeri Sembilan

Johor

Kedah

Perak

Melaka

Pahang

Sarawak
13,534

18,455

3239

2403

4074

180

76
$6,690,500$

$5,636,470$

$3,291,500$

$1,022,289$

690,499

144,628

22,525

$68,190,364$

Source: Malaysian Association of Hotel (2020)

In term of hotel closure, based on survey done by the Malaysian Association Hotel (MAH) of 324 hotels, $15 \%$ hotel closed permanently, 35\% temporary closed and 50\% no closure planned. Table 2 below shows the distribution in detail:

Table 2. Hotel responses on closure

\begin{tabular}{lll}
\hline & No of responses & $\%$ of responses \\
\hline Permanent & 48 & $15 \%$ \\
Temporary & 114 & $35 \%$ \\
No closure planned & 162 & $50 \%$ \\
Total & 324 & $100 \%$ \\
\hline
\end{tabular}

Source: Malaysia Association of Hotel (2020)

Immediate strategies have been done by many hotels and still formulating strategies in order to survive in the market during this pandemic. Many hotels have entered into negotiations with their employees to discuss on employees' terms and conditions of employment. However, hotels were forced to make difficult decisions to place employees on unpaid leaves, pay-cuts and even laying off employees. In the survey done by Malaysian Association of Hotels (MAH) based on 41,000 employees, findings revealed that $26 \%$ of employees had been given unpaid leaves, $20 \%$ taken pay-cuts while $6 \%$ were laid off. Table 3 below shows the details of the survey.

Table 3. Employment measures taken on employees

\begin{tabular}{lccc}
\hline \multicolumn{1}{c}{ State } & $\begin{array}{c}\text { Employees Given } \\
\text { Pay-Cut }\end{array}$ & $\begin{array}{c}\text { Employees Given } \\
\text { Unpaid Leave }\end{array}$ & Employees Laid Off \\
\hline Kedah (Langkawi) & $33 \%$ & $39 \%$ & $3 \%$ \\
Perlis & $0 \%$ & $0 \%$ & $0 \%$ \\
Penang & $19 \%$ & $12 \%$ & $1 \%$ \\
Perak & $30 \%$ & $41 \%$ & $12 \%$ \\
Selangor & $32 \%$ & $25 \%$ & $6 \%$ \\
Kuala Lumpur & $22 \%$ & $28 \%$ & $3 \%$ \\
Negeri Sembilan & $6 \%$ & $29 \%$ & $11 \%$ \\
Melaka & $4 \%$ & $31 \%$ & $15 \%$ \\
Johor & $32 \%$ & $9 \%$ & $12 \%$
\end{tabular}


Pahang

Terengganu

Kelantan

Sabah

Sarawak

Total

\section{$0 \%$}

$5 \%$

$2 \%$

$14 \%$

$10 \%$

$20 \%$ 2021, Vol. 11, No. 1

*Source: Malaysian Association Hotel (2020)

\section{Methodology}

This research was carried out qualitatively through semi-structured interviews. As this research investigated the impact of COVID-19 on hotel industry in Malaysia, qualitative approach was more suitable to gain deeper understanding and meaning. The informants were selected by purposive sampling techniques (Johnston \& Sabin, 2010) and willingness to participate. Despite no definite number of participants required for specific qualitative research, Creswell (1998) suggested 5 to 25 participants, while Morse (1994) suggested that at least 6 participants are sufficient for the phenomenological studies. Initially, the researcher has approached eight hotels to participate in this research and six hotels were willing to participate and agreed to be interviewed. The six hotel representative agreed to become an informant for this study and shared information on current status of their operation due to COVID-19 pandemic. Table 4 shows the details of the informants. Based on the consent given, the location of the hotels allowed to be exposed but the identity and other informants' information were not revealed. To protect confidentiality of the hotels, pseudonym was created to the participating hotels. On the other hand, due to limited time and Malaysia was still under recovery movement control order (RMCO) the interview was done by using online application Cisco Webex and each interview session was audio-recorded. The interview were conducted in English and no problem arose during the interview process. Due to the objectives of this research, the recordings were transcribe and analyzed manually.

Table 4. Informants Profile

\begin{tabular}{llc}
\hline Pseudonym & Location & Hotel Rating \\
\hline Hotel A & Johor Bahru & 5 \\
Hotel B & Sarawak & 5 \\
Hotel C & Putrajaya & 4 \\
Hotel D & Kuantan, Pahang & 4 \\
Hotel E & Sabah & 3 \\
Hotel F & Tioman, Pahang & 3 \\
\hline
\end{tabular}

\section{Discussion}

\section{Hotel Industry view on COVID-19}

The first restriction Movement Control Order (MCO) ordered by the Malaysian government on the 18 March 2020 has given huge impact to Malaysia. The country's economy is losing RM2.4 billion everyday due to business suspension during the movement control order 


\section{Macrothink}

International Journal of Human Resource Studies ISSN 2162-3058 2021, Vol. 11, No. 1

(Timbuong, 2020). To be specific on hotel industry, on average, every 14 days of MCO will cost the hotel industry RM500 million in losses. The industry is anticipating a ban on mass gatherings for the next six months and, thereafter, it would be dependent on the situation at the time (MAH, 2020). However, the MCO was necessary to curb the spread of COVID-19 and save lives despite knowing that it would paralyses Malaysia's economic growth. Indeed, this order lead to drastic changes in hotel industry since Malaysian have a complete restriction of movement nationwide. The following quotation were the view from the hotel informants when they described on COVID-19 pandemic:

"COVID-19 is one of the deadly pandemic that has shaken the world. It is cannot be seen or feel."

Hotel Sabah

"It's a huge natural disaster impacted all of our industries almost to the ground. Other countries also affected by this pandemic in terms of economic, business, society, and tourism."

Hotel Putrajaya

"COVID-19 is a worldwide war which affect the movement of human from doing their daily routine. This pandemic affects worldwide economy where many operations need to be closed down and affect the business revenue."

Hotel Johor Bahru

"First of all, even after the crisis, occupancy will continue to suffer for the remainder of 2020 and probably well into 2021 "

Hotel Kuantan Pahang

Sadly, one informant revealed his true feeling when describing about COVID-19. With experience of 30 years in hospitality industry the pandemic has changed his passion in this hotel industry and never consider career in hospitality anymore.

"Worst for hospitality industry. We around globe closed 98 hotels. My experience in my life time hospitality career of 30 years. Never seen a pandemic put entire hospitality worker in jobless. Now I will never consider a career in hospitality."

Hotel Sarawak

\section{The Impact of COVID-19 on Hotel Industry}

Most of the major industries in Malaysia are dealing with the effects of COVID-19. They not only need to slow down their business operations but also lead to a reduction in customers demand. According to Aldaihani \& Ali (2018) cancellation of travel and tour packages affects mostly the hotels and airlines business because it was expecting millions of guests. Due to increasing number of COVID-19 cases, hotels are prohibited to accept new guest and all activities, function and services remain closed. With low visitor arrivals and the implementation of new norms of social distancing, hotel industry is entering a great crisis as the impacts of COVID-19 pandemic (Foo et al., 2020). Based on the findings, the informants claimed that this pandemic has negative impact to their business operation. This can be 
proved by the following comments:

"This pandemic has affected the hotel through many ways such as guests arrival has dropped badly, room occupancy dropped to single digit and at certain days zero. No international and local travelers wanted to stay at the hotel, no banquet functions as all the government functions are cancelled and customers are afraid to eat at food and beverages outlets in the hotel."

Hotel Sabah

"Since COVID-19 spreads around the world, our hotel receives only a few guests where the border between countries are closed and mostly our guest is an international guest. We faced a huge loss due to this pandemic. But, affective on $18^{\text {th }}$ March, MCO started and our hotel also restricted to receive any guest including Malaysian guest. We only receive guest who are categorized in essential service category with a letter from their company stated that they are working in that category."

Hotel Johor Bahru

"Room Booking, weddings and other MICE activities would be postponed, as well as other social and corporate events. Even when recovery is taking place, it is probably that some kind of travel restriction continues, which will diminish demand as well."

Hotel Kuantan Pahang

Furthermore, hotels in Malaysia also reported a loss of revenue once people avoid travelling, mass gathering and event during the pandemic. Some of the informants shared that they faced huge loss and need to find a strategy that have an immediate impact on the survival of the business in COVID-19 crisis. The comments were as follow:

"As of 18 Mac 2020 till middle of June 2020, our occupancy tremendously dropped from $60 \%$ to single digit. Hotels have already lost more than RM5 million in revenue since March till June 2020 (combinations of room revenue and others such as $F \& B$ and MICE)"

Hotel Kuantan Pahang

"As MCO affective in March, we faced a huge loss because we already targeted to gain a big revenue during Ramadhan buffet. We need to change our menu to Ala carte but still offer Malaysian cuisine. Besides, we also need to reduce the usage of utilities such as electricity. Lights and air condition in the area that are not in use will be switched off."

Hotel Johor Bahru

"No guests, no diners, no wedding, all catering, restaurant and bar closed. We lost $70 \%$ revenue from Food and Beverage. All associate sent for leave first 30 days to control wages."

Hotel Sarawak 
Hotel employees are the worst affected during this global economic uncertainty due to COVID-19. Some of them being laid off and take unpaid leave, and this situation also led to drastic decline in occupancy rates of hotel industry. According to Kaur (2020), the hotel should achieve $40 \%$ of average occupancy to break even with additional income from food and beverages, events and retail. However, sales of the hotel drastically decrease reflecting the severity of the crisis. As commented by the hotel informants:

"Almost 30-40\% of direct hotel employees laid off. Individual hotels and major operators are projecting occupancies below 20\%. If demand stays low, hotel will not have the capacity to absorb the same size of labour force they had pre-crisis. In addition, the bigger the risk for hotel companies to lose qualified employees. Not many people in Malaysia can sustain three to six consecutive months without pay, and hotel is not the exception."

Hotel Kuantan Pahang

"My hotel is in the tourism industry and our whole business has been cancelled and postponed. Also, our occupancy drops to zero percent."

Hotel Putrajaya

Based on the findings, hotel informants shared that they still operate the business with limited services only for in-house guests. One of the informants claimed that the hotel considers extra precaution in operating the business and implementing health and safety guidelines to reduce the risk of exposure to employees and customers.

"Due to this pandemic, our hotel is stricter in receiving outsiders. Anyone who come to the hotel for business purpose need to undergo temperature checking and their details will be recorded. Even staffs, their temperature also must be recorded everyday during clock in and clock out."

Hotel Johor Bahru

"No, we did not close. We look for immediate business by calling the Oil Company which has platforms in Sarawak water for 60 units. So, we capture 150 room for period of 6 month. This contract end August 2020. We don't not have any fit guest during this pandemic and guest facility all closed."

Hotel Sarawak

\section{The Tourism Stimulus Package offered by the Government}

Government announced stimulus packages and various incentives to help affected business included hotel industry to counter the impact of the outbreak (MAH, 2020). Malaysia government has introduced economic stimulus package to boost Malaysia tourism which in turn help the hotel industry (Table 5). Therefore, this package has been released mainly to ease the cash flow of tourism and affected sector and also to help in stimulate demand for travel and tourism (Flanders et al., 2020). 
Table 5. Economic Stimulus Package for tourism industry

Benefits for tourism industry

- deferment of monthly income tax instalment payments for businesses in the tourism sector for 6 months

- $15 \%$ discount in monthly electricity bills to hotels agencies for 6 months starting April 2020

- $6 \%$ service tax exemption for hotels from March to August 2020

- RM600 one-off-payment to tourist bus drivers and tourist guides

- personal income tax exemption up to RM1000 on domestic tourism spending

- digital voucher for domestic tourism up to RM100 per person for domestic flights, rails and hotel accommodation with RM500 million allocation for the voucher and tourism promotion

- relaxation of existing guidelines to limit the use of hotels by government agencies

- double deduction on expenses for training related to tourism that has been approved

- RM100 million on a matching grant basis to HRDF.

Source: Ministry of Finance Malaysia (2020)

Based on the findings, one of the informant claims that this packages really help the industry to survive and recover. The informant comment was as follows:

"It really helped us since our cost is increasing. We can cover back our personnel monthly salary and other expenses. Also, tourism tax was excluded this year until year 2021."

Hotel Putrajaya

On the other hand, findings show that informants agreed hotel industry needs specific hotel stimulus plan to ease their financial burden. However, informants stated that their hotel still have not received the stimulus plan yet as per the interview was conducted. Similarly, informant commented on the stimulus packages. Below are the comments from the managers,

"It supports in terms of paying staff salary where SOCSO RM1200 for 3 months has helped but not for the total lock down period. The support is not enough as we still have to pay the staff in full when we open the business. Furthermore, the support is not enough throughout the recovery stage. This is the highest costs in our expenses. We were unable to get some packages as of due to the investors in this hotel."

\section{Hotel Tioman Pahang}

"Only recently SEB (Sabah Electrical Board) give discounts on electric bill. This has no effect as we have no occupancy or revenue and yet we have to pay the bills in full of little discount. We never gotten any similar packages."

Hotel Sabah

"None been confirmed. We run out of cash. Nothing we have received until now after submitting all the documents. It very slow process. Hotel calling everyday but no fruitful answer. That the reason many hotels are closing because they don't have 
revenue to pay the employees. Package announce but poor coordination and quick response to the affected industry."

Hotel Sarawak

However, negative views were received during the interview. Two managers from the hotel in Sabah and Sarawak have not received the stimulus package yet. According to the informant, the procedure took longer time to receive and unable to get the Government's stimulus package due to the investors in his hotel. This situation has led to problems in businesses' cash flow and has forced hotel operations to be suspended. Furthermore, MCO has slowed the process of getting the incentives particularly at the MCO's early stage. It is due to the planning and policy making by the government to legalize any item that was released through government incentive.

\section{Short-Term and Long-Term Strategies}

Many hotels in Malaysia have to develop short-term and long-term strategies to survive due to the COVID-19 pandemic. Hotel operation under MCO still allowed but to operate at minimal level, in compliance with guidelines issued by the Ministry of Tourism, Arts and Culture such as accommodation services are allowed for guests whom had checked in before 18 March 2020 and long-stay guests as well as personnel from essential services gazette by the Government. In addition, the Government also used hotels as a quarantine center to support the hotel industry. More hotel operators have been urged to make their respective premises available to be utilised as quarantine centres for Malaysians returning from abroad. Malaysia has 190 quarantine centres across the country including hotels where 17,008 people are accommodated for a mandatory quarantine period of 14 days (Perimbanayagam \& Landau, 2020). Hotels' involvement as a quarantine center would be exempted from Sales and Services Tax. This statement confirmed in the interview, one manager saying,

"During MCO, Ministry of Tourism, Arts and Culture has offered our hotel to be the Quarantine Centre for Person under surveillance (PUS) arrived from oversea. Their budget proposed was not high but we quickly accepted with no choice",

Hotel Putrajaya

The hotel industry witnessed business dropped to almost zero while having to bear overheads and payroll costs over the same period. The evidence obtained from the Malaysian Association Hotel (2020) for the Hotel Occupancy and Revenue estimated loss of revenue. Table 6 below highlights the details which found the loss were almost Ringgit Malaysia 3 billion. 
Table 6. Malaysia Hotel Occupancy and revenue January - June 2019/2020 Forecast

\begin{tabular}{lcccl}
\hline & 2019 & 2020 & $\begin{array}{l}\text { Estimated Loss of } \\
\text { Room Revenue } \\
(\mathrm{RM})\end{array}$ \\
\hline & Occupancy (\%) & $\begin{array}{c}\text { Average } \\
\text { Daily Rates } \\
\text { (RM) }\end{array}$ & Occupancy \% & $\begin{array}{l}\text { Based on 200,000 } \\
\text { star rated hotel } \\
\text { rooms only }\end{array}$ \\
\hline January & & & $(49,452,130)$ \\
February & 58.5 & 227.89 & 55 & $(327,527,183)$ \\
Mac & 68 & 238.07 & 44 & $(596,085,583)$ \\
April & 65 & 223.64 & 22 & $(1,126,568,133)$ \\
May & 65 & 219.55 & 6 & $(537,093,414)$ \\
June & 53 & 206.70 & 11 & $(660,172,500)$ \\
Total & 64 & 228.75 & 16 & $(3,296,898,943)$ \\
\hline
\end{tabular}

Source: Malaysian Association Hotel (2020)

*Based on survey of 94,000 rooms inventory, using 2019 average room rates. Not inclusive of food beverage and events/functions losses

Based on interview with the hotel informants, following are the short-term strategies shared by the hotel informants. The qualitative evidence for this 'reality' can be found in the findings as shown by the following quote from one of the managers:

"There are 4 immediate strategies done in our hotel. We sold packages with 30\% discounts which guest can stay anytime. We also implement the Revenue Management Best Available Rate and transform strategy to local tourist"

Hotel Tioman, Pahang

Hotel managers in the interview commented and expressed their thoughts about the strategies:

"Local destination tourism where we create own packages and sell through e-marketing and social media. Guest pay now and can stay either 5 or 10 nights. We also implement Revenue Management Best Available Rate and front liners packages"

Hotel Sabah

"Now we reduced our rates to attract guest to return back to our hotel. Also, we followed the guidelines set of New Norms by Malaysian National Security Council"

Hotel Putrajaya

"We did some take away and delivery for $F \& B$, but it was poor response due to everyone do not have money to buy"

Hotel Sarawak

"Hotel will carefully evaluate any redundancy in operations and will take this opportunity to make opportunistic changes. Operational departments would be 
consolidated, and many positions won't be refilled. We may operate with $20 \%$ or $30 \%$ less of its workforce in most cases"

Hotel Kuantan Pahang

What is the next plan for hotel strategies in the long run? Drastic measures have to be taken for hotels to survive. Profit maximization is not in the equation for now; cost-cutting exercises are possibly the only option available. Hotel industry do not have a choice. Planning and determination are needed to remain in the industry. It takes planning and commitment to stay inside the industry. Payroll is one of the largest hotel operating expenses and typically accounts for 25 to 35 percent of overall revenue. Hotels in Malaysia typically have a staffing ratio of 0.8 to 1.5 ; or even 3 to 3.5 in luxury premium hotels. Compared to hotels in developed countries, these figures mean that the productivity of workers in Malaysia is low. Optimization of the operations can be done in the 0.4 to 0.5 range. Until this ratio can be reached the correct organizational structure needs to be in place. A lot of duties can be outsourced to reduce the headcount. This will depend on whether the arrangement of the hotel is horizontal or vertical, since the latter requires a higher ratio (Chew, 2020)

In respond to this statement, the hotel managers agreed proposed suggestion by Chew, (2020)

"Reduce staff if this pandemic continues, reduce salary and staff based on 1 room 0.4 staff strength, reduce costs with no OT, reduce purchases of unnecessary items"

Hotel Sabah

"Our hotel did management wage cut which for General manager-50\%, Executive $40 \%$ and Manager is 30\%. If there is still no business for next 3 months may be staff will go through VSS or termination.

Hotel Sarawak

"Due to MCO, many departments in the hotel did not have any business such as Banquet, Club Lounge, Sales and Marketing and Bar. So, cross-department has been done in order to ensure workers still have a job to do even there is no business in their department. Cross-department need to be done due to retrenchment program and finally result to less manpower. By doing that, we move as a team where those from other department need to change their role by working in other department. For example, Housekeeping Department that mainly use outsource worker need to be covered by workers from Banquet Department"

Hotel Johor Bahru

On the other hand, questions also asked on the long-term strategies to tackle this COVID-19 pandemic.

"We foresee this pandemic will over by 6 months. International border needs to open to penetrate the business market. We can depend on domestic market because we have room incentive, function room incentive, wedding incentive next 3 months"

\section{Hotel Sarawak}

"Currently our hotel performance is fall back from 2 years ago. We are expecting recovery in year 2022. Our business strategies need to align with current market demand and supply" 
Hotel Putrajaya

"Our hotel to be more focus on domestic markets and will actively involve in social media advertising. We also will actively offer the package and special room rates to all market segmentation"

Hotel Kuantan Pahang

Another manager from hotel added,

"Our hotel will reduce staff if this pandemic continue, reduce costs with no OT and reduce purchases of unnecessary items",

Hotel Tioman Pahang

\section{Conclusion}

Overall, this research shed some light on hotel industry in which has experience devastating situation. To date, the hotel industry still facing a very tough and difficult time since the implementation of MCO. Furthermore, the implementation of entry ban and borders closure turned hotel industry into a struggle time. This research shared the reality of what the hoteliers facing now on impact of COVID-19. This research also highlighted the current and long-term strategies taken by the hotel to sustain in the industry. The findings of this research come up with a few managerial implications for the Malaysian hotel industry. Firstly, the views, experiences and voices shared by the hotel informants hoped will be heard by the Tourism Ministry Culture and Art, authorities, and agencies to better 'feel' the reality facing by the hotel industry. The best solutions still depending on the hotel itself to formulate strategies that best suit their operation. Secondly, the Tourism Stimulus Package offered by the Government with various measures hoped managed to ease the burden of hotel industry businesses. Findings from this research disclosed the Tourism Stimulus Package received, aid the hotels in terms of capital funds and cash flow to sustain their businesses and retain their employees. Therefore, it is recommended that the hotel industry manage their cost-cutting and strengthen strategies on local tourism. Even though the border is still close, domestic tourism will play a major role in the hotel industry's recovery. Local visitors would be an important factor in filling the gap, which will turn into driving the economy of the hotel. Additionally, in light with incentives given by the Government, Visit Malaysia year 2020 is now turning to domestic tourism in order to compensate for the decline in international arrivals. Hotel industry need to grab this opportunity to craft attractive packages to attract more local visitors.

\section{Acknowledgement}

The researchers would like to thank Hotel A in Johor Bahru, Hotel B in Sarawak, Hotel C in Putrajaya, Hotel D in Kuantan, Pahang, Hotel E in Sabah and Hotel F in Tioman Island, Pahang for participating in this research. Your time, commitment and willingness to participate in this research is greatly appreciated. 


\section{References}

Aldaihani, F. M. F., \& Ali, N. A. (2018). Factors Affecting Customer Loyalty in the Restaurant Service Industry in Kuwait City, Kuwait. Journal of International Business and Management, 1(2), 1-14.

Chew, H. (2020). What's next for the hotel industry? Retrieved June 24, 2020 from the Star https://www.thestar.com.my/business/business-news/2020/04/16/whats-next-for-the-hotel-ind ustry

Creswell, J. W. (1998). Qualitative Inquiry and Research Design: Choosing Among Five Traditions. Thousand Oaks, CA: Sage Publications.

Flanders, S., Nungsari, M., \& Hui, Y. C. (2020). The COVID-19 Hardship Survey: An Evaluation of the Prihatin Rakyat Economic Stimulus Package. Asia School of Business Discussion Paper Series. Retrieved June 25, 2020 from https://www.researchgate.net/publication/340769013_The_COVID-19_Hardship_Survey_An _Evaluation_of_the_Prihatin_Rakyat_Economic_Stimulus_Package

Foo, L. P., Chin, M. Y., Tan, K. L., \& Phuah, K. T. (2020). The impact of COVID-19 on tourism industry in Malaysia. Current Issues in Tourism, DOI: 10.1080/13683500.2020.1777951 Malaysian Association of Hotel (MAH). (2020). Short Term Economic Plan but What About Tourism? https://doi.org/10.1080/13683500.2020.1777951

Johnston, G., L., \& Sabin, K. (2010). Sampling Hard-To-Reach populations with respondent $\begin{array}{lllll}\text { driven } & \text { sampling. } & \text { Methodological } & \text { Innovations, } & 5(2),\end{array}$ https://doi.org/10.4256/mio.2010.0017

Kaur, S. (2020). Hotels in KL Partially Sloce for Business. Retrieved June 25, 2020 from New Straits Times https://www.nst.com.my/property/2020/03/579988/hotels-kl-partially-closed-business

Malaysian Association of Hotel (MAH). (2020). http://www.hotels.org.my/press

Ministry of Finance Malaysia. (2020). 2020 Economic Stimulus Package "Bolstering Confidence, Stimulating Growth \& Protecting Jobs". Retrieved June 25, 2020 from https://www1.treasury.gov.my/pdf/pre2020/Speech_2020_Economic_Stimulus_Package.pdf

Ministry of Heath Malaysia. (2020). Situasi Semasa Pandemik COVID-19 Di Malaysia. Retrieved June 28, 2020 from http://covid-19.moh.gov.my/

Morse, J. M. (1994). Designing funded qualitative research. In Denizin, N. K. \& Lincoln, Y. S., Handbook of qualitative research (2nd Ed). Thousand Oaks, CA: Sage

Perimbanayagam, K., \& Landau, E. (2020). More hotels needed to quarantine returning Malaysians. Retrieved June 23, 2020 from the New Straits Times. https://www.nst.com.my/news/nation/2020/04/585529/more-hotels-needed-quarantine-returni ng-malaysians 


\section{Macrothink}

International Journal of Human Resource Studies

ISSN 2162-3058 2021, Vol. 11, No. 1

Timbuong, J. (2020). Our economy loses RM2.4bil every day MCO is active, says PM. Retrieved June 23, 2020 from the Star. https://www.thestar.com.my/news/nation/2020/04/25/our-economy-loses-rm24bil-every-daymco-is-active-says-pm

Worldometer. (2020). Countries where COVID-19 has Spread, Retrieved December 11, 2020 from https://www.worldometers.info/coronavirus/\#countries

Ying, T. P. (2020, June 23). Hotels badly affected by cancellation. Retrieved June, 23, 2020 from New Straits Times: https://www.nst.com.my/news/nation/2020/03/575491/hotels-badly-affected-cancellations

\section{Copyright Disclaimer}

Copyright for this article is retained by the author(s), with first publication rights granted to the journal.

This is an open-access article distributed under the terms and conditions of the Creative Commons Attribution license (http://creativecommons.org/licenses/by/4.0/). 